\title{
Correlation between malondialdehyde and metanephrine in patients with acute lymphoblastic leukemia
}

\author{
Jwan A. Zainulabdeen* \\ Received 22, October, 2013 \\ Accepted 6, November, 2013
}

\begin{abstract}
:
Acute lymphoblastic leukemia (ALL) is one of the most common diseases, so in this study the serum level of malondialdehyde and its relationship with metanephrine was investigated in acute lymphoblastic leukemia patients over one month of treatment.

Some biochemical parameters (serum glucose, total serum protein , malondialdehyde ,vitamin C, and metanephrine) changed as well as white blood cell count and blood hemoglobinlevelswere analyzed in sixty patients diagnosed with acute lymphoblastic leukemia over one month of treatment compared to healthy control group.

Statistically significant increases $(p<0.01)$ in white blood cell (WBC) count, mean concentrations of malondialdehyde (MDA) $(p<0.05)$ and metanephrine $(p<0.001)$ were observed in contrast significant decreases in blood hemoglobin $(p<0.001)$ ,random blood glucose $(p<0.01)$ and total serum protein $(p<0.01)$ were determined in ALL patients group than that control group. Meanwhile the results showed a positive correlation $(p<0.001)$ between metanephrine and MDA in ALL patients in comparison to control. The results in the present study indicate a possible link between increased metanephrine levels of cells alterations due to oxidative damage.
\end{abstract}

Key words: Acute Lymphoblastic Leukemia, Metanephrine, Total serum Protein ,Malondialdehyde, and Vitamin C.

\section{Introduction:}

Acute lymphoblastic leukemia (ALL) is cancer of the white blood cells categorized by excess lymphoblasts [1].Acute lymphoblastic leukemia is most common in childhood with a peak occurrence at 2-5 years of age, and another peak in old age. The overall cure rate in children is about $80 \%$, and about $45 \%-60 \%$ of adults have long-term disease-free survival. Both genetic and environmental risk factors have been implicated in the pathogenesis of this cancer of the hematopoietic system, but their implications have not been fully understood and appreciated [2]. Some of the environmental features that have been examined so far consist of ionizing radiation,infections, electromagnetic fields, chemicals, but only ionizing radiation has been consistently associated with childhood leukemia[3].Several study showed no association of family history of cancer with childhood ALL, while providing additional signal for an inverse association with family history of allergic disease[4].

Diet has been linked with many types of cancer, foods with high fat content may confer to the risk of childhood leukemia, whereas milk and dairy products might have a protective role [5]. A large percentage of children undergoing treatment for ALL have insufficient intakes of antioxidants and vitamin A. Lower intakes of antioxidants are associatedwith increases in the opposing side effects of chemotherapy. Greater vitamin C intakes were associated with fewer therapy delays, less toxicity, and fewer

\footnotetext{
*Department of Chemistry, College of Science, University of Baghdad, Iraq.
} 
days spent in the hospital [6] ,meanwhile treatment strategies should be tailored by age[7].Metanephrine $(\mathrm{MN})$ is metabolite of the adrenomedullary hormones epinephrine produced by action of catechol-O-methyl transferase (EC 2.1.1.6) on it,Vanillylmandelic acid synthesis from oxidative deamination of $O$-methylated catecholamine metabolites metanephrines, this occurs mainly in the liver and leaving very little else to escape into the hepatic venous effluent [6], $\mathrm{MN}$ is present in urine mainly as sulfate- and glucuronide- conjugated metabolites produced from free $\mathrm{MN}$ by the actions of conjugating enzymes. The measurement of plasma free metanephrines is considered to be the best instrument in the diagnosis of pheochromocytoma [6-9].

Reactive oxygen species (ROS) not only as beneficial substances such as in chemotherapy and cancer apoptosis [10,11], but have also established their role in carcinogenesis $[10,12]$.Increased ROS formation and decreased competence of the antioxidant defense not only causes the permanent variation of bimolecular structures but also their functions[11,13].The autocatalytic process of oxidative destruction to polyunsaturated fatty acids caused by hydroxyl radicals and oxygen generates markers of lipid damage such as 4- hydroxynonenal and malondialdehyde (MDA) [14] .

The aim of this study was to evaluate the correlation between MDA (as the indices of lipid peroxidation) and $\mathrm{MN}$ in plasma of ALL patients.AS our knowledge this is the first study deals with MN in ALL disease.

\section{Materials and Methods:}

The patients of Acute Lymphoblastic Leukemia(ALL) as they were submitted to the Protection of Children Hospital Medical City in Baghdad, Iraq were selected for this study. The diagnosis for ALL based on the following findings: leukocyte count, age, involvement of tissues other than bone marrow. Different individuals were selected as control healthy groups. Venous blood samples (10) ml was drawn from (60) patients of ALL ranging between (1-16) years old, after one month postchemotherapy treatment.

Venous blood samples have been collected into three vacationer tubes, one containing EDTA for measurement of blood hemoglobin $(\mathrm{Hb})$, WBC count. The plasma was separated by centrifugation at 3000 rpm for 15 minutes, then transferred immediately to a clean dry plain tube and anticoagulant tube for measuring metanephrine. The blood in the third part was allowed to clot for at least 1015 min. at room temperature, centrifuged for (10) min. at (4000xg). Serum was removed for the measurement of biochemical parameters. Blood was obtained from (30) healthy individuals ranging in age between (1-16) years as a control group. They presented no acute or chronic diseases such as diabetes, or any immune dysfunction. Also, the control used in this study had normal leukocytes and other blood cell counts and made no use of pharmacological therapy.

The serum glucose and total serum protein levels were measured by spectrophotometric methods supplied by randox Diagnostic. Serum malondialdehydewas determined according to the modified method of Benge J.A.1978[15].Vitamin C levels were estimated by the method of Tietz [16]. The plasma metanephrinewere measured by Enzyme Linked Immunosorbent Assay (ELISA) (Demeditec Diagnostics GmbH, Germany).Protein electrophoresis was 
carried using cellulose acetate paper. All statistical analyses in studies were performed using SPSS version 15.0 for Windows (Statistical Package for Social Science, Inc., Chicago, IL, USA). Descriptive analysis was used to show the mean and standard deviation of variables. The significance of difference between mean values was estimated by Student T-Test. The probability $p<0.05=$ significant, $p>$ $0.05=$ non-significant .Correlation analysis was used to test the linear relationship between parameters. ANOVA test was used to show the differences between variables of differentiated groups.

\section{Results and Discussion:}

The results presented in tables (1 and 2) are age and gender distribution of the study groups, respectively, based on the analysis of data on a total of 90 postchemotherapy cases which comprises the following: sixty cases diagnosis of ALL ,30male and 30 female, with age ranged from (1-16) years in comparison with healthy control: consisted of 30 cases healthy that were not complained from any disease.

Table 1: The age distribution of study groups

\begin{tabular}{|c|c|c|c|c|}
\hline \multirow{2}{*}{ Age [year] } & Patients group & \multicolumn{2}{|c|}{ Control group } \\
\cline { 2 - 5 } & No & $\%$ & No & $\%$ \\
\hline $1-8$ & 33 & 55 & 16 & 53.33 \\
\hline $9-16$ & 27 & 44 & 14 & 46.67 \\
\hline
\end{tabular}

*Significant at 0.05 level of significance.

Table 2: The gender distribution of study groups

\begin{tabular}{|c|c|c|c|c|}
\hline \multirow{2}{*}{} & \multicolumn{2}{|c|}{ Patients group } & \multicolumn{2}{c|}{ Control group } \\
\cline { 2 - 5 } & No & $\%$ & No & $\%$ \\
\hline Male & 30 & 50 & 14 & 46.67 \\
\hline Female & 30 & 50 & 16 & 53.33 \\
\hline
\end{tabular}

*Significant at 0.05 level of significance.

The demographic and hematological changes that were observed among the age groups are presented in table (3). These results indicated that there was a significant increase in white blood cell (WBC) count $(p<0.01)$ with a significant decrease in both hemoglobin $(\mathrm{Hb})$ concentration $(p<0.001)$ and $\mathrm{PCV}$ percentage $(p<0.001)$ in sera of ALL patients group as compared with that of the control group, while a nonsignificant differences was observed according to the age.

Table 3: Demographic and hematological data of different studied groups (Mean \pm SD)

\begin{tabular}{|c|c|c|c|}
\hline Characteristic & $\begin{array}{c}\text { Patients } \\
\text { group } \\
{[\mathbf{n = 6 0}]}\end{array}$ & $\begin{array}{c}\text { Control } \\
\text { group } \\
{[\mathbf{n = 3 0 ]}}\end{array}$ & $\begin{array}{c}\boldsymbol{p} \\
\text { Value }\end{array}$ \\
\hline Age [year] & $7.53 \pm 3.48$ & $7.00 \pm 4.09$ & $>0.05$ \\
\hline $\mathrm{Hb}[\mathrm{g} / \mathrm{dl}]$ & $9.31 \pm 1.4$ & $11.57 \pm 0.75$ & $\begin{array}{c}<0.00 \\
1\end{array}$ \\
\hline $\mathrm{PCV} \%$ & $30.06 \pm 5.03$ & $37.27 \pm 2.41$ & $\begin{array}{c}<0.00 \\
1\end{array}$ \\
\hline $\begin{array}{c}\mathrm{WBC}^{*} 10^{3} \text { cell/ } \\
\mathrm{ml}\end{array}$ & $9.15 \pm 0.39$ & $7.21 \pm 0.97$ & $<0.01$ \\
\hline
\end{tabular}

*Significant at 0.05 level of significance.

Pathogenic mechanisms of anemia in cancer patients is hemolysis in erythrocytes, so the results in this study indicated that the $\mathrm{Hb}$ levels decreased significantly in the patients of and ALL after chemotherapy as compared to the healthy $(p<0.001)$, table 3 , while the WBC counts were found to be increased significantly $(p<0.01)$, butin spite of the high count of $\mathrm{WBC}$, there are shortage of normal forms i.e. since childhood leukemia like all cancers is a product of two or more molecular changes in stem-like cells that have the ability to divide while maintaining an immature state.

Table (4) illustrated the biochemical parameters represented by [random serum glucose(R.S.G.), total serum protein (T.S.P.),MDA, vitamin $\mathrm{C}$, and $\mathrm{MN}$ levels of two studied groups ALL patients in comparison to control group]. 


Table 4: The biochemical
parameters of different studied
groups (Mean $\mathbf{\pm}$ SD)
\begin{tabular}{|c|c|c|c|}
\hline Characteristic & $\begin{array}{c}\text { Patients } \\
\text { group } \\
{[\mathbf{n}=\mathbf{6 0}]}\end{array}$ & $\begin{array}{c}\text { Control } \\
\text { group } \\
\mathbf{n}=\mathbf{3 0}]\end{array}$ & $\begin{array}{c}\boldsymbol{p} \\
\text { value }\end{array}$ \\
\hline R.S.G[mg/dl] & $79.92 \pm 16.43$ & $91.23 \pm 11.51$ & $<0.01$ \\
\hline T.S. P[g/dl] & $6.25 \pm 1.10$ & $6.95 \pm 0.57$ & $<0.01$ \\
\hline $\begin{array}{c}\text { MDA } \\
{[\mathrm{nmol} / \mathrm{ml}]}\end{array}$ & $2.46 \pm 0.24$ & $1.55 \pm 0.21$ & $<0.05$ \\
\hline $\begin{array}{c}\text { Vitamin C } \\
{[\mathrm{mg} / \mathrm{dl}]}\end{array}$ & $2.06 \pm 0.13$ & $2.08 \pm 0.20$ & $>0.05$ \\
\hline $\mathrm{MN}[\mathrm{pg} / \mathrm{dl}]$ & $84.69 \pm 29.75$ & $48.75 \pm 7.77$ & $<0.001$ \\
\hline
\end{tabular}

As shown from table (4) changes of R.S.G, T.S.P ,MDA, and MN levels were assessed by comparing control groups blood values with values obtained fromALL patient's ,where R.S.G, T.S.P decreased significantly $\quad(p<0.01$, from $\quad 91.23$ $\pm 11.51 \mathrm{mg} / \mathrm{dl}$ to $79.92 \pm 16.43 \mathrm{mg} / \mathrm{dl}$, and $p<0.01$, from $6.95 \pm 0.57 \mathrm{~g} /$ dlto6.25 $\pm 1.10 \mathrm{~g} / \mathrm{dl}$, respectively ), while MDA and $\mathrm{MN}$ concentrations increased significantly $(p<0.05$, from $1.55 \pm 0.21$ $\mathrm{nmol} / \mathrm{ml}$ to $2.46 \pm 0.24 \mathrm{nmol} / \mathrm{ml}$ ) , and $(p<0.001$, from $48.75 \pm 7.77 \mathrm{pg} / \mathrm{dl}$ to $84.69 \pm 29.75 \mathrm{pg} / \mathrm{dl}$ ), respectively, while in contract there was no significant change in vitamin $C$ levels between the two groups.

Also, the patients group had an approximate similar vitamin $\mathrm{C}$ concentration that of control $(2.06 \pm 0.13$ vs. $2.08 \pm 0.20, p>0.05)$, that may associated with patient nutrition i.e. inadequate intakes of vitamin $\mathrm{C}$ because the requirement for this important antioxidant vitamin may be greater in children with ALL [6] especially during chemotherapy.

The patients in the present study reflected random hypoglycemia $(79.92 \pm 16.43 \quad$ vs. $91.23 \pm 11.51$, $p<0.001)$ during induction therapy, this is in agreement with previous study in which A patient with acute lymphoblastic leukemia repeatedly developed hypoglycemia during chemotherapy. Comparison of serum glucose trends between chemotherapy with and without L-asparaginase demonstrated a strong association between L-Asp and hypoglycemia. Critical blood sampling during hypoglycemia indicated hyperinsulinism, suggesting that L-Asp induced hypoglycemia in the patient through inappropriate insulin secretion [17], also tumor cells overexpress hexokinase or insulin like growth factor-1 increase glycolysis, which raises the glucose level, and consequently, proliferates tumor cells again. Since tumor cells use anaerobic metabolism despite the existence of oxygen, a lot of glucose turns to lactic acid [18-20].

Oxidative stress studies on various types of cancer have indicated increased MDA levels as compared to normal individuals [11, 21-23]. These findings correlate with the levels of MDA measured in our study $(28.10 \pm$ $2.90 \mathrm{nmol} / \mathrm{L}$ vs. $9.20 \pm 0.30 \mathrm{nmol} / \mathrm{L})$ where a significant increase $(p<$ 0.0001) was observed in ALL patients as compared to healthy individuals ,table 4 ,these results were in accordance with those of earlier studies $[11,24,25]$.

In order to clarify the
correlation between these two parameters (MN and MDA) within each of the studied groups, the results were reanalyzed by using linear regression analysis. A positive correlation was established between plasma MN and MDA in sera of patients group under studied only ( $\mathrm{n}=60, \mathrm{r}=0.67, \quad p<0.01)$, but not for control $\operatorname{group}(\mathrm{n}=30, \mathrm{r}=0.08, \quad p>0.05)$ ,(figure 1).

A direct correlation between MDA and cell proliferation with increased lipid damage in highly proliferated cells has been noted [26]. On another study showed that the elevated DNA, lipid and protein oxidation may have occurred as a 
result of a weakened defenses system [27].This suggestion supports the present findings where a decrease in T.S.P $(6.25 \pm 1.10$ vs. $6.95 \pm$ $0.57, p<0.01)$ observed may be due to the increased lipid peroxidation observed. However, it should be noted that .It has been reported that certain lipid peroxidation products like MDA can attack the sulfhydryl groups and the amino group in proteins [28].

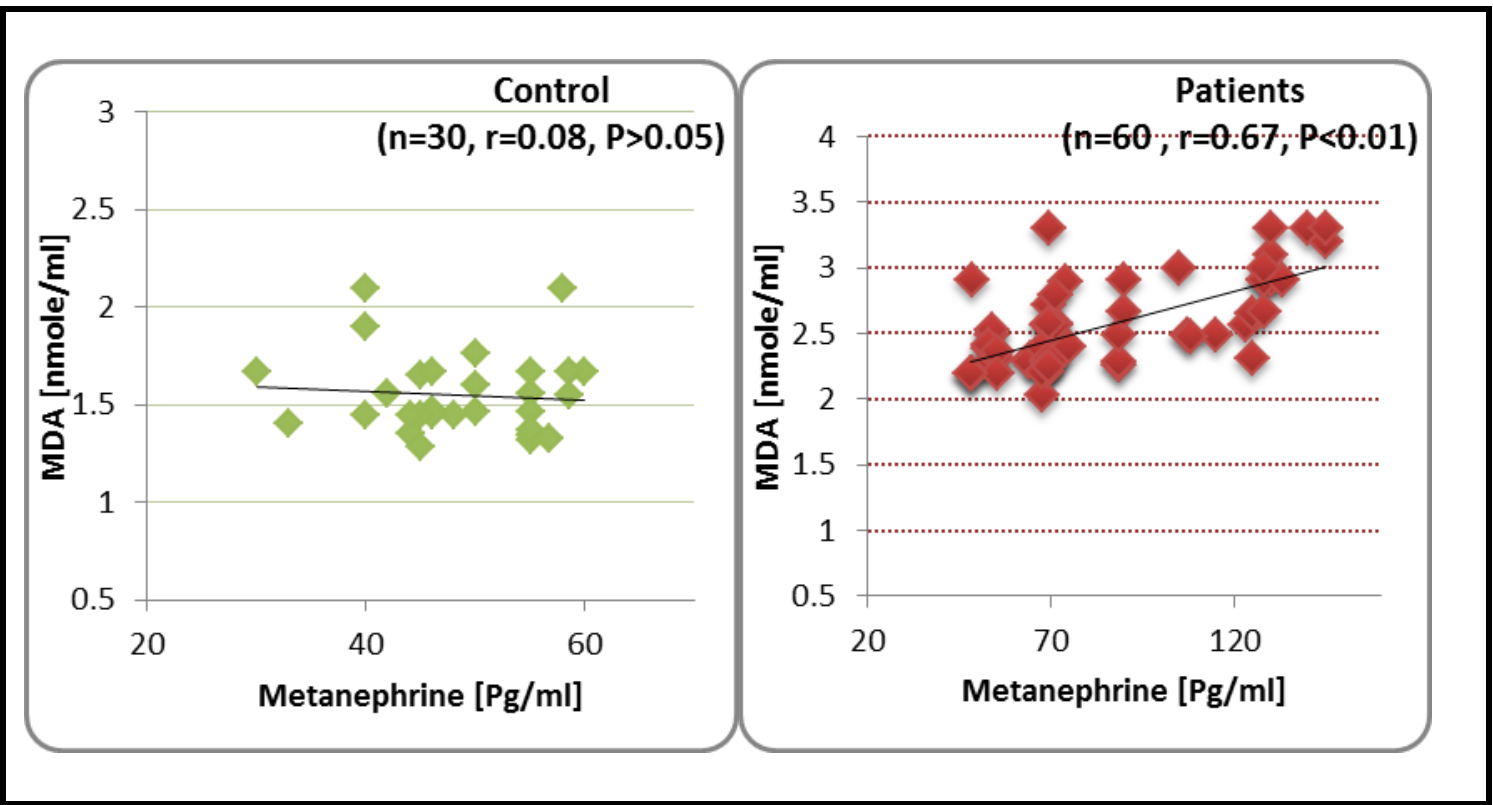

Fig. 1: The correlation between plasma MN and MDA insamples of patients group and control group.

The present study showed that an increase in the mean level of $\mathrm{MN}$ $(28.10 \pm 2.90 \mathrm{nmol} / \mathrm{L}, p<0.0001)$ in the ALL patient group when compared to control group as shown in table 4, that leads to a significant correlation between $\mathrm{MN}(\mathrm{n}=60, \mathrm{r}=0.67, p<0.001)$ in these samples, however, the correlation was not significant for control group $(\mathrm{n}=30, \mathrm{r}=0.08, p>0.05)$, (figure 1). This positive correlation confirmed that the oxidative stress presented in treated patients with ALL disease demonstrated by the increased levels of MDA as a consequence of abnormality in antioxidative metabolism due to the cancer process which significantly progresses by the effect of the chemotherapymight lead to compensatory increased level of the $\mathrm{MN}$ in these patients.

Results of the biochemical parameters for the two studied groups according to age, and gender are given on tables (5 and 6), respectively .It is clear from the results in table (5)that there were no significant differences $(p>0.05)$ of all biochemical parameters (except for $\mathrm{MN}$ levels,$p<0.05$ ) in samples of ALL patient group in comparison to that of the control group , while the results presented in table (6) reveals non- significant difference $(p>0.05)$ in all biochemical parameters in samples of the two studied groups. 
Table 5:The biochemical parameters in patients group according age (Mean \pm SD)

\begin{tabular}{|c|c|c|c|}
\hline Characteristic & $\begin{array}{c}\text { Patients } \\
\text { group } \\
\text { [Age 1-8 } \\
\text { year] }\end{array}$ & $\begin{array}{c}\text { Control } \\
\text { group } \\
\text { [Age 9-16 } \\
\text { year] }\end{array}$ & $\begin{array}{c}\boldsymbol{p} \\
\text { Value }\end{array}$ \\
\hline R.S.G[mg/dl] & $77.15 \pm 13.5$ & $83.30 \pm 19.13$ & $>0.05$ \\
\hline T.S. P [g/dl] & $6.13 \pm 1.10$ & $6.39 \pm 1.13$ & $>0.05$ \\
\hline $\begin{array}{c}\text { MDA } \\
{[\mathrm{nmol} / \mathrm{ml}]}\end{array}$ & $2.43 \pm 0.19$ & $2.49 \pm 0.30$ & $>0.05$ \\
\hline $\begin{array}{c}\text { Vitamin C } \\
{[\mathrm{mg} / \mathrm{dl}]}\end{array}$ & $2.08 \pm 0.13$ & $2.04 \pm 0.12$ & $>0.05$ \\
\hline $\mathrm{MN}[\mathrm{pg} / \mathrm{dl}]$ & $\begin{array}{c}80.44 \\
\pm 26.69\end{array}$ & $89.88 \pm 32.87$ & $<0.05$ \\
\hline
\end{tabular}

Table 6: The biochemical parameters in patients group according gender (Mean \pm SD)

\begin{tabular}{|c|c|c|c|}
\hline Characteristic & $\begin{array}{c}\text { Patients } \\
\text { group } \\
\text { [female] }\end{array}$ & $\begin{array}{c}\text { Control } \\
\text { group } \\
\text { [male] }\end{array}$ & $\begin{array}{c}\boldsymbol{p} \\
\text { Value }\end{array}$ \\
\hline R.S.G[mg/dl] & $\begin{array}{c}78.50 \\
\pm 12.32\end{array}$ & $81.33 \pm 19.83$ & $>0.05$ \\
\hline T.S. P [g/dl] & $6.20 \pm 1.34$ & $6.30 \pm 0.82$ & $>0.05$ \\
\hline $\begin{array}{c}\text { MDA } \\
{[\mathrm{nmol} / \mathrm{ml}]}\end{array}$ & $2.40 \pm 0.22$ & $2.52 \pm 0.25$ & $>0.05$ \\
\hline $\begin{array}{c}\text { Vitamin C } \\
{[\mathrm{mg} / \mathrm{dl}]}\end{array}$ & $2.07 \pm 0.11$ & $2.05 \pm 0.14$ & $>0.05$ \\
\hline MN [pg/dl] & $\begin{array}{c}84.51 \\
\pm 30.01\end{array}$ & $84.87 \pm 29.99$ & $>0.05$ \\
\hline
\end{tabular}

To differentiate between protein patterns cellulose acetate electrophoresis was carried out on sera samples of control and patients groups then separated serum protein bands were detected using ponceau S-stain., figures 2.This figure indicated that the sera was separated into distinct bands by which the separation of different proteins is based on the differences of both molecular size and the charge of these proteins and there is a clear difference in proteins band intensity, which reflects the significant variation in proteins concentration between the studied groups.

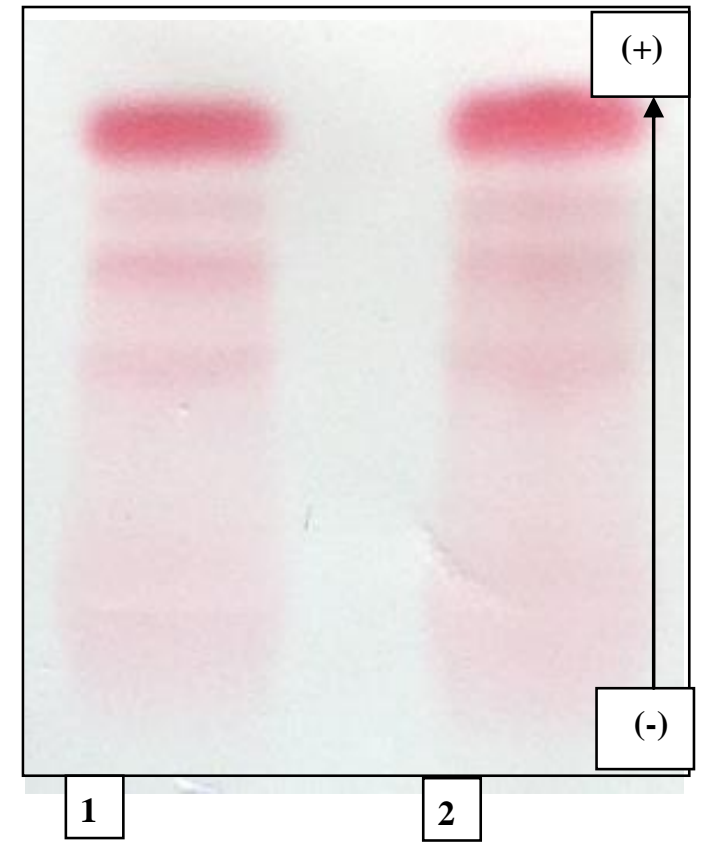

Fig.2. Electrogramof proteins profile samples, (The crude samples that applied were:1: pooled crude sera (patient) ;2: pooled crude sera (control).

The present results suggest an oxidative stress presented in patients with ALL demonstrated by the increased levels of MDA as a consequence of abnormality in antioxidative metabolism due to the cancer process which may be increased after chemotherapy. The oxidative stress might lead to compensatory increased level of the $\mathrm{MN}$ in these patients Moreover, to maintain $\mathrm{MN}$ levels constant, the rate of $\mathrm{MN}$ turnover(i.e., loss of $\mathrm{MN}$ due to metabolism or escape to the bloodstream) must be balanced by an equal rate of synthesis, also the increasing metanephrin's levels may be due to the decreases in catabolism in compression with anabolism .Also the concentration of epinephrine increase the degradation of glycogen [29], so the decreases in R.B.S. levels may stimulate the excretion of epinephrine, as a consequence increasing $\mathrm{MN}$ levels ,table 4.

Comparisons of control to ALL patient's plasma concentrations of 
R.S.G. ,T.S.P. , MDA, and vitamin C levels show negligible or relatively small differences according to age or gender (tables 5and 6), while $\mathrm{MN}$ levels differ significantly according to age.

The results of the present study seem that chemotherapy causes these changes as a result of huge production of ROS in the patients with ALL.

Assessment the effect of antioxidant supplementation to improve antioxidant status in these patients is worth to be carried out in future. Moreover to evaluate the diagnostic performances of plasma total metanephrine in ALL disease, it's levels must be estimated before chemotherapy and in combination with24-h urinary metanephrine.

\section{References}

1. Pui C H, Robison L L, and Look A T. 2008. Acute lymphoblastic leukaemia,Lancet. 371: 1030-1043.

2. WiemelsJ.2012. Perspectives on the causes of childhood leukemia, ChemBiolInteract.196 : 59-67.

3. McNally RJ, and Parker L .2006. Environmental factors and childhood acute leukemias and lymphomas, Leuk Lymphoma. 47:583-598.

4. ZierhutH ,Linet M S , Robison L L,Severson RK, and Spector L.2012.Family history of cancer and non-malignant diseases and risk of childhood acute lymphoblastic leukemia: A Children's Oncology Group Study, Cancer Epidemiol. 36:45-51.

5. Diamantaras AA, Dessypris N, Sergentanis TN, Ntouvelis E, Athanasiadou-Piperopoulou F, Baka M, Fragandrea I, Moschovi M, Polychronopoulou S, Stiakaki E, Panagiotakos D, andPetridou E. 2013.Nutrition in early life and risk of childhood leukemia: a case- control study in Greece, Cancer Causes Control.24:117-124.

6. Kennedy D D , Tucker K L, Ladas E D, Rheingold S.R., Blumberg J., and Kelly K.M. 2004. Low antioxidant vitamin intakes are associated with increases in adverse effects of chemotherapy in children with acute lymphoblastic leukemia, Am J Clin Nutr.79:1029 -1036.

7. Narayanan S, and Shami P J . 2012. Treatment of acute lymphoblastic leukemia in adults, Crit Rev in Oncol Hemat.81:94-102.

8. Lenders JW, Pacak K, Walther MM, Linehan WM, Mannelli M, Friberg P, Keiser HR, Goldstein DS, and Eisenhofer G.2002. Biochemical diagnosis of pheochromocytoma: which test is best?.JAMA.287:1427-1434.

9. Roden M. 2002.How to detect pheochromocytomas? The diagnostic relevance of plasma free metanephrines, WienKlinWochensc hr.114(7):246-251.

10. Dean BJF, andWhitwell D.2009. Epidemiology of bone and softtissue sarcomas, Ortho Trauma. 23:223-230.

11. Battisti V, Maders LDK, Bagatini MD, Santos KF, Spanevello RM, Maldonado PA, Brulé AO, AraújoMdo C, Schetinger MR, and Morsch VM. 2008. Measurement of oxidative stress and antioxidant status in acute lymphoblastic leukaemia patients, J Clin Biochem. 41:511-518.

12. Klaunig JE, Kamendulis LM, and HocevarBA . 2010.Oxidative stress and oxidative damage in carcinogenesis, SocToxicol Path. 38:96-109.

13. KrystonaT B , Georgieva A B , Pissis $\mathrm{P}$, andGeorgakilasa A $\mathrm{G}$. 2011.Review Role of oxidative stress and DNA damage in human carcinogenesis, Mutat. Res. 711:193-201. 
14. Perez-Matute $\mathrm{P}$, Zulet MA, andMartinez JA. 2009. Reactive species and diabetes: counteracting oxidative stress to improve health, CurrOpinPharmacol.9:771-779.

15. Benge J A, and Aust S D .1978., Estimation of serum Malondialdehyde level in hoffee P.A .and Jones M.E. (eds), Methods in Enzymology Hoffee Jones. Academic Press, New York, San Francisco, London, ASubsidinary of Harcoart Brace Jovanovich, Publisher, 51: 302.

16. Tietz N W. 1986.Textbook of Clinical Chemistry. $2^{\text {nd }}$ ed., Sanders W.B. Company-London.

17. Tanaka R ,Osumi $\mathrm{T}$, Miharu M , Ishii T, Hasegawa T., Takahashi T., and Shimada H. 2012. Hypoglycemia associated with Lasparaginase in acute lymphoblastic leukemia treatment: a case report, Exp Hematol Oncol .1:8-11.

18. SillosEM,Shenep JL, Burghen GA, Pui CH, Behm FG, and Sandlund JT. 2001. Lactic acidosis: a metabolic complication of hematologic malignancies: case report and review of the literature ,Cancer.92:2237- 2246.

19. De Keulenaer B, Van Outryve S, and De Backer A. 2003. Symptomatic lactic acidosis due to relapse of T-cell acute lymphoblastic leukaemia in the kidney, Nephrol Dial Transplant. 18:1214-1216.

20. GökçeM, ÜnallŞ , Gülşen H , Başaran O, Cetin M, Gümrük F,andBeşbaş N, Gürgey A. 2012. A rare metabolic complication of acute lymphoblastic leukemia in childhood: lactic acidosis, Turkish J of Pediatr.54: 61-63.

21. GadjevaV, Kutchukova D, Aladjov E , and Georgieva R. 2005. Correlation between Plasma Malondialdehyde and Ceruloplasmin activity in Patients with Malignant Haematological Diseases, TJS.3(2):29-33.

22. Chang D, Wang $F$, Zhao $Y$, andPan H. 2008. Evaluation of oxidative stress in colorectal cancer patients, J Biomed Envir. Scien. 21:286-289.

23. Mazor D, Abucoider A, Meyerstein $\mathrm{N}$,andKapelushnik J. 2008. Antioxidant status in pediatric acute lymphocytic leukemia (ALL) and solid tumors: The impact of oxidative stress,JPediatr Blood Cancer.51:613-615.

24. Singh V, Kaushik M, Dahiya K, Ghalaut PS, Dhankhar R, and Singh R. 2012. Erythrocytic Pyruvate Kinase and Malondialdehyde Levels in Acute Leukaemia Patients ,JCDR. 6:361 - 363.

25. Singh V, Ghalaut PS, Kharb S, andSingh GP. 2001. Plasma concentrations of lipid peroxidation products in children with acute leukaemia, Indian $\mathrm{J}$ Med Sci.. 55(4):215-217.

26. Niedernhofer LJ, Daniels JS, and Rouzer CA. 2003. Malondialdehyde, a product of lipid peroxidation, is mutagenic in human cells,JBiol Chem. 278:31426-433.

27. Badjatia N, Satyam A, Singh P,Seth A, and Sharma A. 2009. Altered antioxidant status and lipid peroxidation in Indian patients with urothelial bladder carcinoma, $\mathbf{J}$ UrolOncol.28:1-8.

28. Devi $G \quad S$,PrasadM $H$, SaraswathiI, Raghu D, Rao D.N, and Reddy P.P.. 2000. Free radicals, anti-oxidant enzymes and lipid peroxidation in different types of leukaemias, Clin Chim Acta. 293: 53-62.

29. Champe P C, Harvey R A, and Ferrier D R. 2008.Lippincott's Illustrated Reviews /Biochemistry, $4^{\text {th }}$ ed., Lippincott Williams \& Wilkins, pp.285. 

العلاقة بين المالونديالد هيدوالميتانيفرين في المرضى الذين يعانون من سرطان الدم الليمفاوي الحاد الترئ

جوان عبد المحسن زين العابلين*

*قنم الكيمياء ،كلية العلوم، جامعة بغداد

يعد مرضلاصة : سرطان الدم الليمفاوي الحاد من الامر اض الثائعة ولذلك تهدف الدراسة الحالية لتحديد مستوى المصل من المالونديالدهيد و علاقته مع ميتانيفرين في مرضى الإنى سرطان الدم الليمفاوي الحادبعد شهر و واحد من (العلاج.

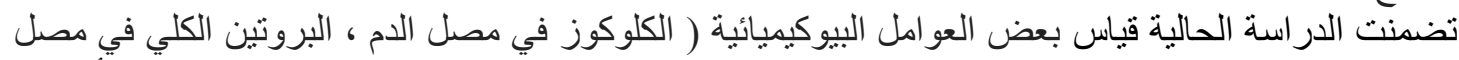

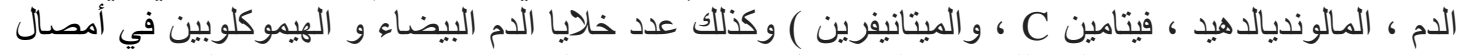

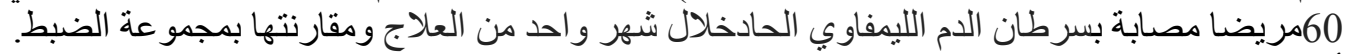

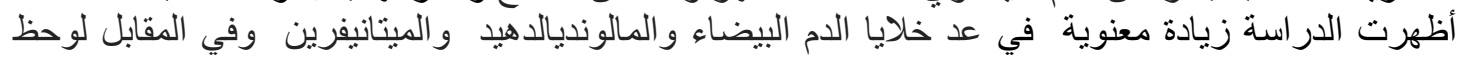

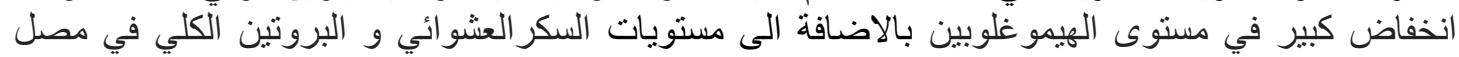

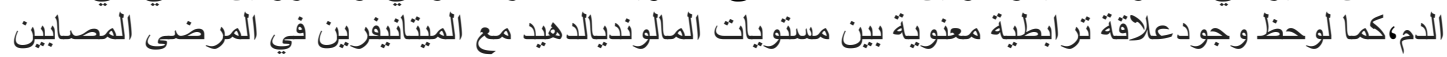

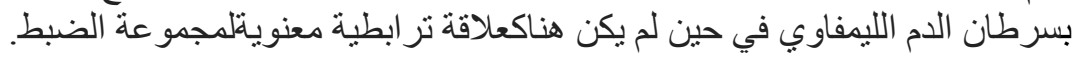

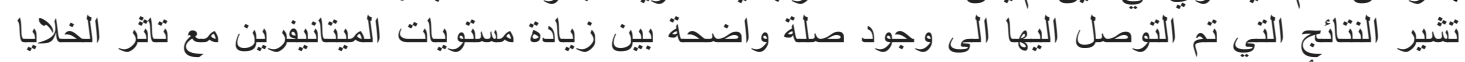
بالضرر التأكسدي. 